\title{
Effect of Transhumant Livestock Grazing on Pseudo-Alpine Grassland Bird Communities
}

\author{
Evangelos G. Kotsonas ${ }^{1}\left(\mathbb{D}\right.$, Dimitrios E. Bakaloudis ${ }^{1, *(\mathbb{D})}$, Christos G. Vlachos ${ }^{1}$, Eleni M. Abraham ${ }^{2}$ (D) \\ and Vassilis Goutner ${ }^{3}$ \\ 1 Laboratory of Wildlife and Freshwater Fish, School of Forestry and Natural Environment, \\ Aristotle University of Thessaloniki, P.O. Box 241, 54124 Thessaloniki, Greece; \\ kotsonas@for.auth.gr (E.G.K.); cvlachos@for.auth.gr (C.G.V.) \\ 2 Laboratory of Range Management, School of Forestry and Natural Environment, \\ Aristotle University of Thessaloniki, P.O. Box 241, 54124 Thessaloniki, Greece; eabraham@for.auth.gr \\ 3 Laboratory of Zoology, School of Biology, Aristotle University of Thessaloniki, P.O. Box 134, \\ 54124 Thessaloniki, Greece; vgoutner@bio.auth.gr \\ * Correspondence: debakaloudis@for.auth.gr; Tel.: +30-2310-992684
}

check for updates

Citation: Kotsonas, E.G.; Bakaloudis, D.E.; Vlachos, C.G.; Abraham, E.M.; Goutner, V. Effect of Transhumant Livestock Grazing on Pseudo-Alpine Grassland Bird Communities. Birds 2021, 2, 23-41. https://doi.org/ $10.3390 /$ birds 2010002

Received: 2 November 2020 Accepted: 6 January 2021 Published: 12 January 2021

Publisher's Note: MDPI stays neutral with regard to jurisdictional clai$\mathrm{ms}$ in published maps and institutional affiliations.

Copyright: (C) 2021 by the authors. Licensee MDPI, Basel, Switzerland. This article is an open access article distributed under the terms and conditions of the Creative Commons Attribution (CC BY) license (https:// creativecommons.org/licenses/by/ $4.0 /)$.
Simple Summary: Transhumance is a human activity that shapes the high-altitude grasslands around the Mediterranean for centuries. However, research on the effects of this husbandry system on birds is limited. In this study, we investigated the effects of grazing transhumant livestock on the pseudo-alpine grassland breeding bird communities in the Pindos Mountains, Central Greece. Two breeding bird surveys were conducted, using 60 point counts, in grasslands with no, low and high grazing intensity to determine whether the bird communities respond to topography and habitat structure resulted by grazing, as well. Results indicated that grasslands with low vegetation height, low height heterogeneity and increased rock cover supported richer and more diverse bird communities. Furthermore, certain bird species of high conservation value appeared to prefer each grassland. Short grass dwelling bird species are associated with grazed grasslands, while tall grass and shrub dwelling birds are associated with non-grazed grasslands. Our results suggest that in order to sustain diverse bird communities of high conservation value in the pseudo-alpine grassland, a mosaic of grazed and ungrazed areas must be retained.

Abstract: Transhumance is a traditional animal husbandry system, but its effects on grassland avian communities have not been dealt with in depth. In this study, we quantified the influence of transhumance on the grassland avifauna, in representative pseudo-alpine grasslands with no (NGG), low (LGG), and high (HGG) grazing intensity in the Pindos Mountains, Central Greece. Two point count surveys were conducted within 20 sites in each grassland during the bird breeding season of 2016. We assessed bird diversity indices and accounted for whether the recorded habitat and topographic variables were involved in their variation. A total of 25 bird species were recorded, with the grazed grasslands supporting the most species of high conservation value, while the NGG showed the highest bird diversity. Bird species richness and diversity increased with the decrease of vegetation height, vegetation height heterogeneity, and the increase of rock cover. Bird communities exhibited different patterns among the three grazing regimes and specific bird species of high conservation value appeared to prefer different grasslands. Six species preferred HGG, one preferred LGG, while two preferred NGG. Our study highlights the necessity of heterogeneous pseudo-alpine grasslands with short and tall grass areas in order to maintain highly diverse bird communities.

Keywords: transhumance; grazing regime; bird community; pseudo-alpine grassland; livestock

\section{Introduction}

Humans have shaped natural ecosystems for thousands of years [1] affecting the distribution and richness of wildlife communities [2,3]. Livestock grazing is one of the most 
common human activities globally [4] and is used in many animal husbandry systems. Transhumance is a traditional stock rearing system in Europe, dating back to ancient times [5], where livestock exploits the upland pastures during the summer period and are moved to lowland pastures in the winter [6-8]. In South Europe grazing by small ruminants shaped the grasslands of the pseudo-alpine zone for centuries [6]. Nowadays, transhumance is considered a valuable practice for the management and conservation of these fragile ecosystems [9], as it involves many ecologically important management techniques that preserve the better exploitation of rangelands [10].

The impacts of grazing on wildlife have been widely studied (e.g., [11-13]), but they are still not well-understood. Thus, they are not universal and affect wildlife in various ways [12]. Grazing directly affects the basic wildlife habitat elements and specifically the vegetation cover, the food and the space, with both overwhelming and detrimental effects on wildlife populations [12,14]. Grazing is considered a useful land management and conservation tool $[13,15]$, because it increases the structural diversity of vegetation and, consequently, the number of suitable microhabitats for a great spectrum of wildlife species that inhabit open landscapes $[16,17]$. However, both high-stocking rates and abandonment of grazing threaten grassland wildlife species [13]. Overgrazing negatively affects the survival and growth of vegetation, which in turn leads to the reduction of suitable cover and food for wildlife and especially for avifauna [12]. Overgrazing can decrease the protective shrub cover that might lead to a decrease of arthropods, the main food for many bird species, and to decreased nest cover, which leads to increased nest losses [18]. Moreover, high densities of herbivores may decrease the nesting success of ground nesting birds through trampling $[13,19,20]$. However, high stocking rates of sheep in Northern Europe showed positive effect on the density of alpine birds [21]. On the other hand, grazing abandonment leads to shrub encroachment into grasslands, thus making unfavorable conditions for open habitat bird species [13]. Nevertheless, the short-term abandonment can have positive effect on those species as it prevents the high encroachment of shrubs [14].

Birds are widely used as indicators to monitor the effects of livestock grazing [14,22,23] due to the wide range of niches they use, their high mobility, and their easy monitoring [24,25]. Grassland birds are highly associated with special vegetation characteristics derived from different management practices [26], with some species being particularly susceptible to habitat changes resulting from grazing regime [27-29]. Grazing intensity [30] and the type of grazing animal [29] affect bird species in different ways, through the shaping of vegetation structure and habitat quality $[3,12,18,31]$. Livestock, through its selective grazing, creates structurally heterogeneous grasslands [13,32]. Some researchers revealed that some bird species, in particular those feeding and nesting on the ground [25], as well as shrub associated species [18], were negatively affected by increasing grazing intensity [33]. Other studies showed that increased grazing benefited ground nesting and foraging bird species, whereas it negatively affected shrub-associated species [27]. These contradictory findings support the idea that grassland bird species require a mosaic of habitats because each species preferences varies widely from tall and dense to short and sparse vegetation $[12,34,35]$. Also, bird species that share common ecological traits and life histories tend to respond in the same way to ecological changes [36]. Consequently, conservationists may use grazing to diversify grasslands in favor of grassland bird species [12,35].

Meanwhile, during the last decades the socioeconomic changes in Europe affected the rural population activities with cascade effects on the landscape $[37,38]$ and consequently, on the biodiversity [39]. Human activities are responsible for a great loss of global biodiversity $[40,41]$ severely affecting the alpine ecosystems [42] and the alpine wildlife populations changed through habitat modifications [43]. Nevertheless, a long-term study on Scandinavian mountains revealed that grazing by Reindeers (Rangifer tarandus) held the grassland habitats stable over the years leading to a stable alpine bird community with fluctuations for some species [44]. Transhumance is a deterministic force shaping natural alpine and pseudo-alpine grasslands for centuries but has disappeared in most 
European countries without extensive research of its ecological effects [10]. However, in South Europe, transhumance still exists albeit with a declining trend [45], leading to progressive woody vegetation encroachment [46] in alpine grasslands with consequences on avian communities [45].

The relationship of transhumance with wildlife has received little attention [45] and the consequences of transhumance abandonment and its different stocking rates on bird communities of the pseudo-alpine zone have not been studied yet at all. Therefore, it is important to understand the effects of transhumant livestock grazing on birds in the fragile pseudo-alpine grassland ecosystems. Within this context, our study aimed to examine how avian communities respond under different grazing regimes caused by transhumant livestock in pseudo-alpine zone. This study focused on natural grasslands occupying the pseudo-alpine zone with and without grazing transhumant herds during the summer period, whose structural vegetation characteristics evolved due to the presence and absence of livestock, respectively. The way that avian communities respond to habitat variables was analyzed in order to highlight the importance of transhumance in maintaining high quality habitats for the conservation of the threatened pseudo-alpine grassland avifauna.

\section{Experimental Section}

\subsection{Study Area}

The study was carried out in the pseudo-alpine zone of the South Pindos Mountain Range (hereafter Pindos Mountains), in the Trikala Prefecture in Thessaly, Central Greece (Figure 1). The climate of the study areas is montane with a uniformly distributed precipitation among the seasons. Mean annual precipitation is $1213 \mathrm{~mm}$ and mean monthly temperatures range from 3.2 to $13.6^{\circ} \mathrm{C}$. The highland areas of the Pindos Mountains are dominated by stony grasslands, composed by the typical vegetation of the Daphno-Festucetalia zone and used by transhumance livestock during the warm period (May-October) of each year. At the end of May, shepherds move their livestock from lowland plain areas in Thessaly to the summits of the Pindos Mountains, where they graze until October when they move back to lowlands. Each summit supports a specific number of small ruminant herds due to the variation in surface and topography. It must be noted that finding grasslands in the pseudo-alpine zone of the mountainous areas in Greece that have a uniform topography and are not affected by grazing livestock is almost impossible since the region has a great topographic variability and has been affected by transhumance for thousands of years. The recreational activities in the area include hunting (especially of Galliformes) during the autumn and winter months (hunting season).

In our study, the grazing regime was determined through intensity and it was estimated by interviewing the shepherds. The grasslands under different grazing regimes were chosen according to the number of grazing livestock, and we assume that they were the most representative of pseudo-alpine zones above the tree-line, and are categorized as follows:

Non-grazed grassland (NGG): This grassland covered an area of 427 ha approximately and extended between 1420 and $1935 \mathrm{~m}$ above sea level (asl). Since 1998, the area has been under environmental management regulation, with a ban on grazing being the major measure.

Low grazing intensity grassland (LGG): This grassland is situated within a Special Area of Conservation ("Kerketio Oros" GR1440002) of the "Natura 2000" network, and extends between 1335 and $2066 \mathrm{~m}$ asl. It covers 424 ha approximately and isgrazed by two mixed herds of sheep and goats comprising 873 animals (2.06 animals per ha).

High grazing intensity grassland (HGG): This grassland is located in the northeast part of the National Park of Tzoumerka, and it covers 421 ha, approximately. Altitudes range between 1310 and $1846 \mathrm{~m}$ asl. This area is characterized by high transhumance with three large mixed herds which consisted of 3491 grazing sheep and goats (8.29 animals per ha). 


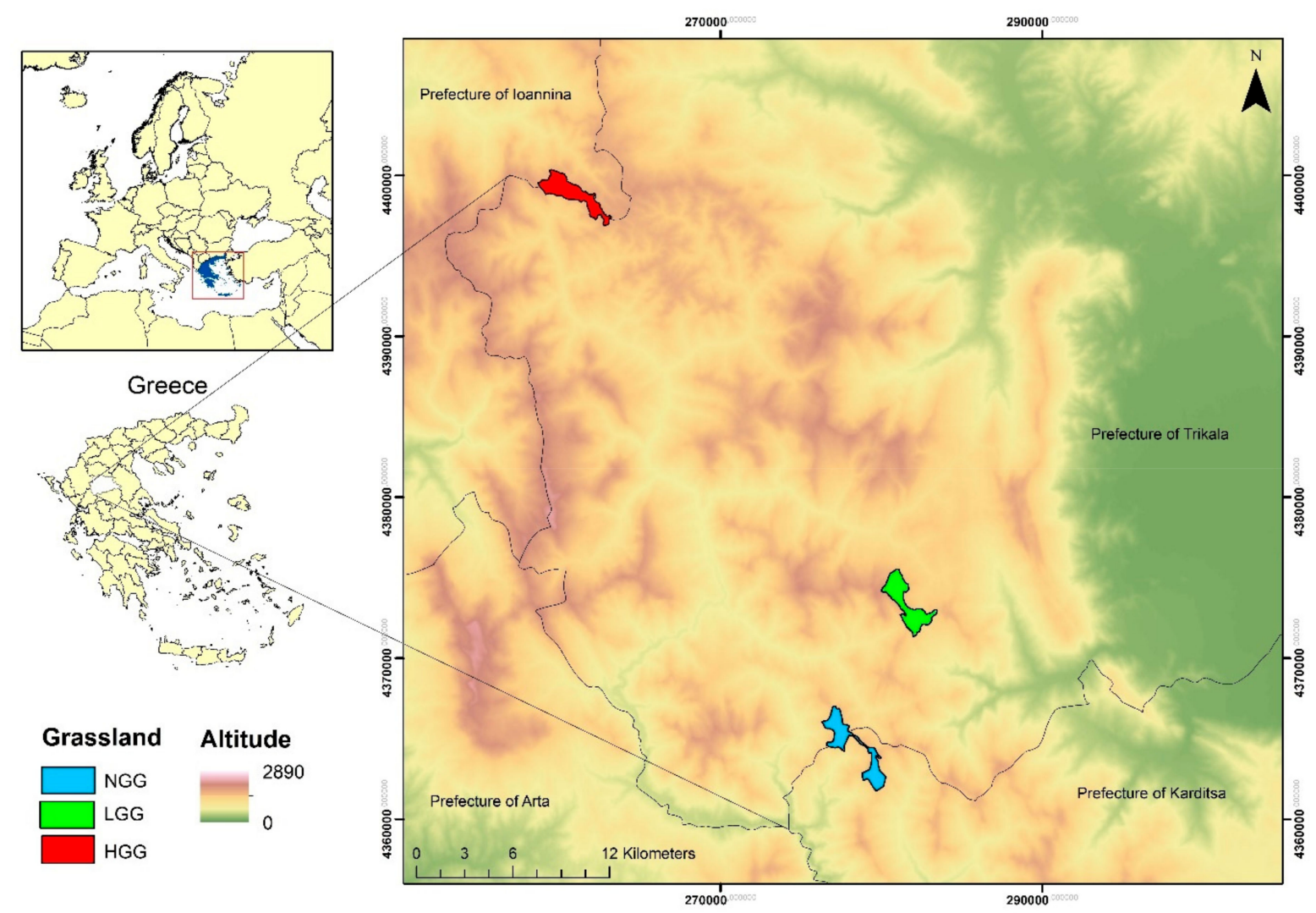

Figure 1. Location of the study area in Central Greece, showing the sampling sites: non-grazed grassland (NGG), low grazing intensity grassland (LGG) and high grazing intensity grassland (HGG).

\subsection{Avian Community Survey}

We used a 50-m fixedradius point count to sample 60 randomly allocated points (20 points in each grassland) across the three grazing regimes during the breeding season of birds (from June to July) in 2016 [47]. In order to record sedentary and migrant breeding bird species, two surveys were conducted in each census point from 8 June to $9 \mathrm{July}$. The three studied grasslands had an average distance of $23.5 \mathrm{~km}$ between them and in each grassland the points were separated by a minimum of $200 \mathrm{~m}$ to avoid double-counting of individual birds at adjacent sites. Point counts were conducted early in the morning and lasted $15 \mathrm{~min}$ [48]. During the first $10 \mathrm{~min}$ one observer (the same person for both surveys) stood still and quiet at the centre of the plot, while for the last $5 \mathrm{~min}$ he moved around and stopped at suitable vantage points to record all seen or heard individuals within the circular plot. Observations of birds flying over during the surveys were not included. Surveys were not conducted in rainy or windy days to reduce problems of detectability. The precise location of survey points was determined by a handheld GPS.

\subsection{Habitat and Topographic Variables}

To determine how the grassland structure changed in relation to grazing regime, we measured 6 habitat and 3 topographic variables within each circular plot. A $50 \mathrm{~m}$ measurement tape was placed with south-north orientation bisecting each point count. We measured the percent of ground cover (herbaceous vegetation, fern, rock and bare ground cover) and herbaceous vegetation height $(\mathrm{H})$ every $1 \mathrm{~m}$ on the interceptions of the measurement tape on the ground. At $1 \mathrm{~m}$ intervals on the interception of the tape to the ground, a steel rod was placed, and the ground category touched by the rod was recorded. Vegetation height was measured by the use of a measurement meter. In each circular plot $(r=50 \mathrm{~m})$ we recorded the presence/absence of shrubs. For each survey point 
topographic variables included slope, altitude and aspect were derived on the center of the plot from a digital elevation model (DEM) in a geographic information system (GIS) archive (ArcGis 10.2.2). We estimated the percent of every ground cover category as the number of intercepts divided by the total intercepts (50) multiplied by 100 . The vegetation height was the mean value of the 50 measurements taken. Moreover, we calculated the heterogeneity of vegetation height $(\mathrm{CV})$ by the equation $\mathrm{CV}=\mathrm{H} / \mathrm{SD}_{\mathrm{H}} \times 100$, with $\mathrm{SD}_{\mathrm{H}}$ the standard deviation of $\mathrm{H}$. All habitat measurements were carried out during May 2016, prior to grazing by livestock [49] which moved to the area by the shepherds during the first week of June.

\subsection{Data Analysis}

\subsubsection{Bird Diversity}

The total bird species diversity of the three grasslands was expressed using four indicators: the species richness (S), the weighted-species richness (WS), the Shannon diversity index $\left(H^{\prime}\right)$ and the Smith and Wilson's index of evenness $\left(E_{\text {var }}\right)[50,51]$. The $\mathrm{S}$ was expressed as the total number of different bird species recorded in each grassland during the two surveys. The WS was expressed as the species richness in each grassland, but each species was multiplied with a different weight based on its conservation status (SPEC category) [52]. Species whose global population is concentrated in Europe, but whose European population status is currently considered to be secure $\left(\right.$ Non-SPEC ${ }^{\mathrm{E}}$ ) and species whose global population is not concentrated in Europe, and whose European population status is currently considered to be secure (Non-SPEC), were given a weight of 1 . Species whose global population is not concentrated in Europe, but which is classified as regionally extinct, critically endangered, endangered, vulnerable, near threatened, declining, depleted or rare at European level (SPEC 3) were given a weight of 2. Species whose global population is concentrated in Europe and which is classified as regionally extinct, critically endangered, endangered, vulnerable, near threatened, declining, depleted, or rare at the European level (SPEC 2) as well as the species of the Annex I of the European Directive 2009/147/EE were given a weight of 4. Finally, European species of global conservation concern, i.e., classified as Critically endangered, endangered, vulnerable, or near threatened at the global level (SPEC 1), were given a weight of 6 . Also, the bird diversity was calculated on every point count and expressed as mean \pm standard deviation (S.D.). The mean species richness $\left(S_{\text {mean }}\right)$ was expressed as the total number of different bird species recorded in each point count during the two surveys, the abundance (A) was expressed by the use of the maximum number of individuals of every species recorded during the two surveys in each point count and the bird diversity $\left(\mathrm{H}^{\prime}\right.$ mean $)$ was calculated by the Shannon diversity index per point count.

\subsubsection{Comparison of Environmental Variables and Bird Diversity Indices}

The habitat and topographic variables (mean \pm 1 standard error (S.E.)), the abundance of every bird species (mean \pm S.D.), and the mean bird diversity indices (mean \pm S.D.) ( $\mathrm{S}_{\text {mean }}, \mathrm{A}, \mathrm{H}_{\text {mean }}^{\prime}$ ) were compared between the NGG, LGG and HGG. We tested for differences between the variables among the three grazing regimes by employing a one-way analysis of variance (ANOVA), while the equivalent non-parametric Kruskal-Wallis test with multiple comparisons was used when the assumption of normality was violated. Pair-wise tests between the variables were also employed. Normally distributed variables were analyzed using t-test for independent samples. Those variables not meeting normality assumptions were analyzed using the non-parametric post hoc Dunn's test with Bonferroni adjustment for multiple comparisons. Prior to analysis, variables were checked for normality (Shapiro-Wilk test) and homoscedasticity (Levene test). When multiple comparisons were carried out, we used the sequential Bonferroni correction to adjust the significance level [53]. 


\subsubsection{Investigation of Alpha Diversity}

Generalized linear mixed models (GLMM) were used to explain the observed variation of avian species diversity $\left(\mathrm{S}_{\text {mean }}, \mathrm{H}^{\prime}\right.$ mean $)$. $\mathrm{S}_{\text {mean }}$ was used as the response variable with a Poisson distribution and a log link function, while the $\mathrm{H}^{\prime}$ mean was used as the response variable with a Normal distribution and an identity link function. The habitat and topographic variables that differed significantly, along with the '\% rock cover' which was marginally significant (Table 1 ), were used in the models. The explanatory variables inserted in the models were '\% rock cover', 'herbaceous vegetation height', 'CV height', 'altitude', 'slope', 'aspect' and 'shrub presence'. A random intercept was inserted as random effect to allow random variation by each grassland. Model comparisons using the corrected Akaike information criterion $\left(\mathrm{AIC}_{\mathrm{C}}\right.$ ) values were used to determine whether terms significantly improved the fit of the model. We built a maximal model with all explanatory variables and through a stepwise-deletion [54] we removed the non-significant terms until only significant terms $(p<0.05)$ were included in the model. Following that model simplification, the non-significant terms were reinserted in the model in order to examine if they improve the fit of the model. The $\mathrm{AIC}_{\mathrm{C}}$ of all the created models were compared with that of the best model (with the lower $\mathrm{AIC}_{\mathrm{C}}$ ) in order to investigate the influence on the fit of the model. Models with $\triangle \mathrm{AIC}_{\mathrm{C}}<2$ were considered to have strong support, those with $2<\Delta \mathrm{AIC}_{\mathrm{C}}<4$ have a moderate support and those with $4<\Delta \mathrm{AIC}_{\mathrm{C}}<8$ have low support [55]. Models with $\triangle \mathrm{AIC}_{\mathrm{C}}>9$ were not presented as they were considered to have little support.

Table 1. Average values ( \pm S.E.) of habitat and topographic variables in three (NGG, LGG, HGG) pseudo-alpine grasslands in Central Greece, and results of ANOVA test. Different capital letters denote significant differences among grazing regimes. The level of significance for pair-wise comparisons was set at $\alpha=0.016$ after the sequential Bonferroni correction.

\begin{tabular}{|c|c|c|c|c|c|c|}
\hline Variables & NGG & LGG & HGG & Statistic & $\mathrm{df}$ & $p$-Value \\
\hline Herbaceous vegetation cover $(\%)$ & $72.6 \pm 3.64$ & $65.9 \pm 6.77$ & $77.6 \pm 5.28$ & $2.652 *$ & 2 & 0.265 \\
\hline Rock cover $(\%)$ & $26.5 \pm 3.74$ & $19.8 \pm 4.04$ & $13.2 \pm 2.9$ & $5.696^{*}$ & 2 & 0.058 \\
\hline Bare ground cover $(\%)$ & $0.1 \pm 0.1$ & $0.3 \pm 0.21$ & $0.0 \pm 0.0$ & 2.104 * & 2 & 0.349 \\
\hline Fern cover $(\%)$ & $0.8 \pm 0.8$ & $14 \pm 7.69$ & $9.2 \pm 4.24$ & 4.177 * & 2 & 0.124 \\
\hline $\begin{array}{l}\text { Herbaceous vegetation height } \\
\qquad(\mathrm{cm})\end{array}$ & $52.32 \pm 1.6^{\mathrm{A}}$ & $26.01 \pm 2.27^{\mathrm{B}}$ & $19.26 \pm 0.54^{\mathrm{B}}$ & 40.598 * & 2 & $<0.001$ \\
\hline $\begin{array}{l}\text { (CV) Vegetation height } \\
\text { heterogeneity }\end{array}$ & $22.56 \pm 0.8^{\mathrm{A}}$ & $59.92 \pm 6.83^{\text {B }}$ & $16.55 \pm 1.94^{C}$ & 22.249 & 2,57 & $<0.001$ \\
\hline Altitude (m) & $1574.3 \pm 18.7^{\mathrm{A}}$ & $1608.6 \pm 31.8^{\mathrm{A}}$ & $1727.15 \pm 14.37^{\text {В }}$ & 12.287 & 2,57 & $<0.001$ \\
\hline Slope $(\%)$ & $23.02 \pm 2.02 \mathrm{~A}$ & $20.28 \pm 1.89 \mathrm{~A}$ & $13.39 \pm 1.41^{\mathrm{B}}$ & 9.412 & 2,57 & $<0.001$ \\
\hline Aspect (degrees) & $89.66 \pm 9.07 \mathrm{~A}$ & $106.72 \pm 19.63^{\mathrm{A}}$ & $186.69 \pm 16.15^{\mathrm{B}}$ & 17.581 * & 2 & $<0.001$ \\
\hline
\end{tabular}

* values are based on non-parametric Kruskal-Wallis test.

\subsubsection{Investigation of Beta Diversity}

Multi-Response Permutation Procedures (MRPP), a non-parametric method, was performed to compare the composition of bird communities of the three pseudo-alpine grasslands, and Sørensen distance was used as our dissimilarity measure [56]. The same method was used between each pair of grassland in order to detect differences in their bird species composition. The test statistic $(T)$ indicates the separation of the groups, and the chance-corrected within-group agreement $(A)$, shows homogeneity within groups. Furthermore, we used indicator species analysis (ISA) [57] with a Monte Carlo randomization test running 1000 times to see which species underlie the differences among the grasslands. The relative abundance (average abundance of a species in a grassland over the average abundance of that species in all grasslands, expressed as a \%) and the relative frequency (\% of plots in a grassland where the species is present) of every species in each grazing regime were used for the calculation of the ISA. Birds that were significant at the 0.05 level were considered as indicator species. 


\subsubsection{Investigation of Gamma Diversity}

To determine the relationship of bird species occurring in grasslands under different grazing regime with habitat and topographic variables, non-metric multidimensional scaling (NMS) was used to construct a graphical representation of sample units in bird species space. NMS was used because it is considered to be the most suitable ordination method of ecological community data, thus it makes few assumptions about the nature of the data [58]. We used 'autopilot (slow and thorough)' mode with random starting configurations and Sørensen (Bray-Curtis) as the distance measure. The number of runs with real data and maximum number of iterations were set at 250 and 500 , respectively. Also, we examined the relationship of the vegetation variables with the ordination axes representing the highest proportion of variance in the bird species data of the final optimum ordination space. The distance between two surveyed points in the ordination of sample scores reflects the relative dissimilarity in their species compositions. We then plotted the habitat and topographic variables as vectors on a joint plot to show their relationships with the bird species scores. The stress value resulted by the analysis were used as a measure for finding the best solution in dimensionality. Values greater than $20 \%$ indicate plots close to random, whereas values smaller than $20 \%$ indicate a useful dimensional picture, and less than $10 \%$ correspond to an ideal ordination [58].

Prior to statistical analyses, variables expressed as percentages were arcsine square root transformed, while all other habitat and topographic variables were log-transformed. Statistical analyses of $t$-test of independence, one-way ANOVA, Kruskal-Wallis, DunnBonferroni, and GLMM were conducted using the statistical package IBM-SPSS Statistics version 25, and other statistical analyses (NMS, MRPP, ISA) conducted using PC-ORD version 5 [56]. The level of significance for all tests was set at 0.05 .

\section{Results}

\subsection{Bird Diversity}

A total of 25 bird species and 416 individuals were recorded across the three studied grasslands (Table 2). Eight more bird species, including the Yellow-billed Chough (Pyrrhocorax graculus), the Raven (Corvus corax), the Hooded Crow (Corvus cornix), the Barn Swallow (Hirundo rustica), the House Martin (Delichon urbicum), the Short-toed Eagle (Circaetus gallicus), the Kestrel (Falco tinnunculus), and the Eurasian Hobby (Falco subbuteo) were observed flying over during surveys and excluded from the analysis. Eleven species, the Eurasian Skylark, the Tawny Pipit, the Tree Pipit, the Corn Bunting, the Rock Bunting, the Yellowhammer, the Red-backed Shrike, the Linnet, the Woodlark, the Northern Wheatear, and the Whinchat showed significant differences in their abundance between the three grasslands (Table 2). Nineteen bird species were recorded in HGG, 16 bird species in LGG, and only 14 bird species in NGG. Most birds occurred with high concentrations in both grazed grasslands were classified as Species of European Conservation concern (SPEC) [52] However, the Shannon diversity index and the Smith and Wilson's index of evenness were higher in the NGG than in grazed grasslands (Table 3). At plot level, the species richness, the bird abundance and diversity were significantly higher in HGG compared to LGG and NGG (Table 3).

\subsection{Comparison of Environmental and Topographic Variables}

The environmental and topographic variables that differed significantly among the three grasslands were the herbaceous vegetation height, the heterogeneity of vegetation height, the altitude, the slope, and the aspect (Table 1). 


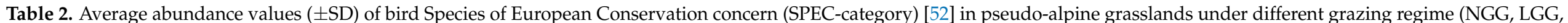

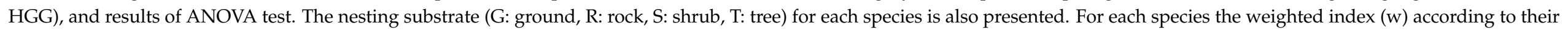

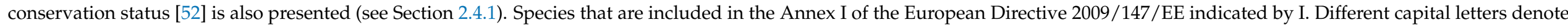

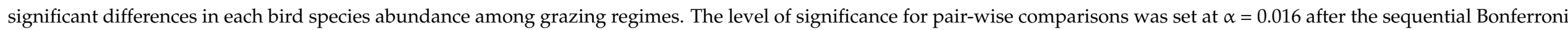
correction.

\begin{tabular}{|c|c|c|c|c|c|c|c|c|c|c|}
\hline Common Name & Scientific Name & Nesting Substrate & SPEC & $\mathbf{W}$ & NGG & LGG & HGG & Statistic & df & $p$-Value \\
\hline Eurasian Skylark & Alauda arvensis & $G$ & 3 & 2 & $0.35 \pm 0.587^{\mathrm{A}}$ & $0.85 \pm 1.040^{\mathrm{A}}$ & $1.80 \pm 0.834^{\mathrm{B}}$ & $22.964 *$ & 2 & $<0.001$ \\
\hline Rock Partridge & Alectoris graeca & $\mathrm{R}, \mathrm{G}$ & 1 & $6^{\mathrm{I}}$ & $0.50 \pm 1.147$ & $0.20 \pm 0.696$ & $0.05 \pm 0.224$ & $2.443 *$ & 2 & 0.295 \\
\hline Tawny Pipit & Anthus campestris & G & 3 & $4^{\mathrm{I}}$ & $0.05 \pm 0.224^{\mathrm{A}}$ & $0.35 \pm 0.587^{\mathrm{A}}$ & $0.05 \pm 0.224^{\mathrm{A}}$ & 7.218 * & 2 & 0.027 \\
\hline Tree Pipit & Anthus trivialis & G & 3 & 2 & $0.45 \pm 0.605^{\mathrm{A}}$ & $0.0 \pm 0.0^{\mathrm{B}}$ & $0.50 \pm 0.761^{\mathrm{A}}$ & 10.614 * & 2 & 0.005 \\
\hline Common Quail & Coturnix coturnix & G & 3 & 2 & $0.40 \pm 0.681$ & $0.15 \pm 0.366$ & $0.25 \pm 0.444$ & 1.556 * & 2 & 0.459 \\
\hline Corn Bunting & Emberiza calandra & G, S & 2 & 4 & $0.40 \pm 0.754^{\mathrm{A}}$ & $0.15 \pm 0.489$ A,B & $0.0 \pm 0.0^{\mathrm{B}}$ & $7.744 *$ & 2 & 0.021 \\
\hline Rock Bunting & Emberiza cia & $G, R, S$ & - & 1 & $0.45 \pm 0.759^{\mathrm{A}}$ & $0.0 \pm 0.0^{\mathrm{B}}$ & $0.0 \pm 0.0^{\mathrm{B}}$ & 15.556 * & 2 & $<0.001$ \\
\hline Yellowhammer & Emberiza citrinella & $\mathrm{G}, \mathrm{S}$ & 2 & 4 & $0.0 \pm 0.0^{\mathrm{A}}$ & $0.10 \pm 0.308^{\mathrm{A}}$ & $0.55 \pm 0.759^{\mathrm{B}}$ & 14.772 * & 2 & 0.001 \\
\hline Ortolan Bunting & Emberiza hortulana & $\mathrm{G}, \mathrm{R}$ & 2 & $4^{\mathrm{I}}$ & $0.65 \pm 1.226$ & $0.40 \pm 0.598$ & $0.10 \pm 0.447$ & $5.760 *$ & 2 & 0.056 \\
\hline Red-backed Shrike & Lanius collurio & $\mathrm{S}, \mathrm{T}$ & 2 & $4^{\mathrm{I}}$ & $0.65 \pm 0.745^{\mathrm{A}}$ & $0.20 \pm 0.696^{\mathrm{B}}$ & $0.65 \pm 0.988^{\mathrm{A}, \mathrm{B}}$ & $7.680 *$ & 2 & 0.021 \\
\hline Common Linnet & Linaria cannabina & $\mathrm{S}, \mathrm{R}, \mathrm{G}, \mathrm{T}$ & 2 & 4 & $0.05 \pm 0.224^{\mathrm{A}}$ & $0.35 \pm 0.813^{\mathrm{A}, \mathrm{B}}$ & $1.20 \pm 2.567^{\mathrm{B}}$ & $7.511 *$ & 2 & 0.023 \\
\hline Woodlark & Lullula arborea & G & 2 & $4^{\mathrm{I}}$ & $0.0 \pm 0.0 \mathrm{~A}$ & $0.10 \pm 0.308^{\mathrm{A}, \mathrm{B}}$ & $0.30 \pm 0.470^{\mathrm{B}}$ & $7.942 *$ & 2 & 0.019 \\
\hline Rufous-tailed Rock Thrush & Monticola saxatilis & $\mathrm{R}$ & 3 & 2 & $0.20 \pm 0.410$ & $0.25 \pm 0.639$ & $0.35 \pm 0.587$ & 1.116 * & 2 & 0.572 \\
\hline Northern Wheatear & Oenanthe oenanthe & $\mathrm{G}, \mathrm{R}$ & 3 & 2 & $0.0 \pm 0.0^{\mathrm{A}}$ & $1.40 \pm 1.273^{\mathrm{B}}$ & $1.60 \pm 1.536^{\mathrm{B}}$ & 24.424 * & 2 & $<0.001$ \\
\hline Great Tit & Parus major & $\mathrm{T}$ & - & 1 & $0.10 \pm 0.308$ & $0.0 \pm 0.0$ & $0.0 \pm 0.0$ & $4.068 *$ & 2 & 0.131 \\
\hline Black Redstart & Phoenicurus ochruros & $\mathrm{R}$ & - & 1 & $0.0 \pm 0.0$ & $0.10 \pm 0.447$ & $0.0 \pm 0.0$ & $2.000 *$ & 2 & 0.368 \\
\hline Whinchat & Saxicola rubetra & G & 2 & 4 & $0.0 \pm 0.0^{\mathrm{A}}$ & $0.20 \pm 0.410^{\mathrm{A}}$ & $0.80 \pm 0.768^{\mathrm{B}}$ & 19.526 * & 2 & $<0.001$ \\
\hline Common Stonechat & Saxicola torquatus & G & - & 1 & $0.10 \pm 0.308$ & $0.0 \pm 0.0$ & $0.10 \pm 0.447$ & $2.002 *$ & 2 & 0.367 \\
\hline European Serin & Serinus serinus & $\mathrm{T}, \mathrm{S}$ & 2 & 4 & $0.0 \pm 0.0$ & $0.10 \pm 0.447$ & $0.0 \pm 0.0$ & $2.000 *$ & 2 & 0.368 \\
\hline Lesser Whitethroat & Sylvia curruca & S & - & 1 & $0.0 \pm 0.0$ & $0.0 \pm 0.0$ & $0.05 \pm 0.224$ & $2.000 *$ & 2 & 0.368 \\
\hline Eurasian Blackbird & Turdus merula & $\mathrm{T}, \mathrm{S}, \mathrm{G}$ & - & 1 & $0.0 \pm 0.0$ & $0.0 \pm 0.0$ & $0.05 \pm 0.224$ & $2.000 *$ & 2 & 0.368 \\
\hline Mistle Thrush & Turdus viscivorus & $\mathrm{T}, \mathrm{R}$ & - & 1 & $0.15 \pm 0.366$ & $0.0 \pm 0.0$ & $0.05 \pm 0.224$ & 3.687 * & 2 & 0.158 \\
\hline
\end{tabular}

* values are based on non-parametric Kruskal-Wallis test. 
Table 3. Average values ( $\pm \mathrm{SD}$ ) of bird diversity indices [species richness (Smean), abundance (A), Shannon diversity index ( $\mathrm{H}^{\prime}$ mean) in pseudo-alpine grasslands under different grazing regime (NGG, LGG, HGG), and results of ANOVA test. Different capital letters denote significant differences in diversity indices among grazing regimes. The level of significance for pair-wise comparisons was set at $\alpha=0.016$ after the sequential Bonferroni correction. The total bird species diversity, (species richness (S), weighted-species richness (WS), Shannon diversity index $\left(\mathrm{H}^{\prime}\right)$ and Smith and Wilson's index of evenness (Evar)) was also presented.

\begin{tabular}{|c|c|c|c|c|c|c|}
\hline Diversity Indices & NGG & LGG & HGG & Statistic & df & $p$-Value \\
\hline$S_{\text {mean }}$ & $3.40 \pm 1.095^{\mathrm{A}}$ & $3.20 \pm 1.105^{\mathrm{A}}$ & $5.30 \pm 1.949^{B}$ & $16.768 *$ & 2 & $<0.001$ \\
\hline A & $4.50 \pm 2.013^{\mathrm{A}}$ & $4.95 \pm 2.373^{\mathrm{A}}$ & $8.55 \pm 3.546^{\mathrm{B}}$ & 18.219 * & 2 & $<0.001$ \\
\hline $\mathrm{H}_{\text {mean }}^{\prime}$ & $1.122 \pm 0.326^{\mathrm{A}}$ & $1.038 \pm 0.375^{\mathrm{B}}$ & $1.490 \pm 0.371^{C}$ & 9.024 & 2,57 & $<0.001$ \\
\hline S & 14 & 16 & 19 & & & \\
\hline WS & 38 & 52 & 50 & & & \\
\hline $\mathrm{H}^{\prime}$ & 3.482 & 3.392 & 3.381 & & & \\
\hline$E_{\mathrm{var}}$ & 0.585 & 0.616 & 0.337 & & & \\
\hline
\end{tabular}

\subsection{Investigation of Alpha Diversity}

The GLMM analysis showed that according to the best model the bird species richness $\left(\mathrm{S}_{\text {mean }}\right)$ significantly increased as the rock cover $(\%)$ increased and the herbaceous vegetation height and the heterogeneity of vegetation height (CV height) decreased. Moreover, the presence of shrubs was not significant but improved the fit of the model (Table 4). The random effect of the best model explained $7.6 \%$ of the total variance. Also, the Shannon diversity index significantly increased with increased \% rock cover and decreased herbaceous vegetation height and heterogeneity of vegetation height (CV height) (Table 5). The random effect of the best model explained $6.1 \%$ of the total variance.

Table 4. Output of GLMM investigating the environmental and topographic factors affecting the bird species richness $\left(S_{\text {mean }}\right)$ on pseudo-alpine grasslands. Models were ranked according to their suitability. Suitable models include those with strong support $\left(\triangle \mathrm{AIC}_{\mathrm{C}}<2\right)$ and those with moderate support $(2<\Delta \mathrm{AIC} C<4)$. Parameter coefficients [Estimate and S.E.] of the best model presented. Random intercept included as random effect to allow random variation by each grassland (7.6\% explained variation). Statistically significant explanatory variables are presented in bold. Inserted explanatory variables are presented with + and their levels as $\mathrm{K}$.

\begin{tabular}{|c|c|c|c|c|c|c|}
\hline Model Rank & Model Name & Explanatory Variables & Deviance & $\mathbf{K}$ & $\mathrm{AIC}_{\mathrm{C}}$ & $\Delta \mathrm{AIC}_{\mathrm{C}}$ \\
\hline 1 & Best & $\begin{array}{c}\text { Herbaceous Vegetation Height }+\% \\
\text { Rock Cover }+ \text { CV height }+ \text { Shrub } \\
\text { Presence }\end{array}$ & 70.018 & 7 & 72.094 & 0 \\
\hline 2 & Final /SuiTable 1 & $\begin{array}{l}\text { Herbaceous Vegetation Height }+\% \\
\text { Rock Cover }+ \text { CV Height }\end{array}$ & 70.589 & 5 & 72.663 & 0.569 \\
\hline 3 & SuiTable 2 & $\begin{array}{l}\text { Herbaceous Vegetation Height }+\% \\
\text { Rock Cover + CV Height + Slope }\end{array}$ & 73.564 & 6 & 75.639 & 3.545 \\
\hline 4 & SuiTable 3 & $\begin{array}{l}\text { Herbaceous Vegetation Height }+\% \\
\text { Rock Cover }+ \text { CV Height }+ \text { Aspect }\end{array}$ & 73.697 & 6 & 75.773 & 3.679 \\
\hline 5 & SuiTable 4 & $\begin{array}{l}\text { Herbaceous Vegetation Height }+\% \\
\text { Rock Cover + CV Height }+ \text { Altitude }\end{array}$ & 73.699 & 6 & 75.774 & 3.680 \\
\hline 6 & UnsuiTable 1 & $\begin{array}{c}\text { Herbaceous Vegetation Height }+\% \\
\text { Rock Cover }+ \text { CV Height }+ \text { Aspect }+ \\
\text { Shrub Presence }\end{array}$ & 75.192 & 8 & 77.269 & 5.175 \\
\hline 7 & UnsuiTable 2 & $\begin{array}{c}\text { Herbaceous Vegetation Height }+\% \\
\text { Rock Cover }+ \text { CV Height }+ \text { Altitude }+ \\
\text { Aspect }+ \text { Shrub Presence }\end{array}$ & 76.577 & 9 & 78.655 & 6.561 \\
\hline 8 & UnsuiTable 3 & $\begin{array}{l}\text { Herbaceous Vegetation Height }+\% \text { Rock } \\
\text { Cover }+ \text { CV Height }+ \text { Altitude }+ \text { Slope }\end{array}$ & 76.673 & 7 & 78.750 & 6.656 \\
\hline
\end{tabular}


Table 4. Cont.

\begin{tabular}{|c|c|c|c|c|c|c|}
\hline Model Rank & Model Name & Explanatory Variables & Deviance & K & $\mathrm{AIC}_{\mathrm{C}}$ & $\Delta \mathrm{AIC}_{\mathrm{C}}$ \\
\hline 9 & UnsuiTable 4 & $\begin{array}{l}\text { Herbaceous Vegetation Height }+\% \text { Rock } \\
\text { Cover + CV Height }+ \text { Altitude }+ \text { Aspect }\end{array}$ & 76.806 & 7 & 78.883 & 6.789 \\
\hline 10 & UnsuiTable 5 & $\begin{array}{c}\text { Herbaceous Vegetation Height }+\% \\
\text { Rock Cover }+ \text { CV Height }+ \text { Altitude }+ \\
\text { Slope }+ \text { Shrub Presence }\end{array}$ & 78.056 & 9 & 80.134 & 8.040 \\
\hline 11 & UnsuiTable 6 & $\begin{array}{c}\text { Herbaceous Vegetation Height }+\% \\
\text { Rock Cover }+ \text { CV Height }+ \text { Slope }+ \\
\text { Aspect }+ \text { Shrub Presence }\end{array}$ & 78.120 & 9 & 80.198 & 8.104 \\
\hline \multirow[t]{7}{*}{12} & $\begin{array}{c}\text { Maximal/ } \\
\text { UnsuiTable } 7\end{array}$ & $\begin{array}{l}\text { Herbaceous Vegetation Height }+\% \\
\text { Rock Cover }+ \text { CV Height }+ \text { Altitude }+ \\
\text { Slope }+ \text { Aspect }+ \text { Shrub Presence }\end{array}$ & 79.470 & 10 & 81.550 & 9.456 \\
\hline & & Best Model & Estimate & S.E. & $t$ & $p$-Value \\
\hline & & Intercept & 1.371 & 0.288 & 4.766 & $<0.001$ \\
\hline & & Herbaceous Vegetation Height & -0.239 & 0.072 & -3.320 & 0.002 \\
\hline & & \% Rock Cover & 0.155 & 0.070 & 2.217 & 0.031 \\
\hline & & CV Height & -0.195 & 0.077 & -2.538 & 0.014 \\
\hline & & Shrub Presence: Absence & -0.073 & 0.142 & -0.517 & 0.607 \\
\hline
\end{tabular}

Table 5. Output of GLMM investigating the environmental and topographic factors affecting the bird Shannon diversity index on pseudo-alpine grasslands. Models were ranked according to their suitability. Suitable models include those with strong support $\left(\triangle \mathrm{AIC}_{\mathrm{C}}<2\right)$ and those with moderate support $\left(2<\Delta \mathrm{AIC}_{\mathrm{C}}<4\right)$. Parameter coefficients [Estimate and S.E.] of the best model presented. Random intercept included as random effect to allow random variation by each grassland (6.1\% variation explained). Statistically significant explanatory variables are presented in bold. Inserted explanatory variables are presented with + and their levels as $\mathrm{K}$.

\begin{tabular}{|c|c|c|c|c|c|c|}
\hline Model Rank & Model Name & Explanatory Variables & Deviance & $\mathbf{K}$ & $\mathrm{AIC}_{\mathrm{C}}$ & $\Delta \mathrm{AIC}_{\mathrm{C}}$ \\
\hline 1 & Final/Best & $\begin{array}{l}\text { Herbaceous Vegetation Height }+\% \\
\text { Rock Cover }+ \text { CV Height }\end{array}$ & 65.305 & 5 & 69.305 & 0 \\
\hline 2 & SuiTable 1 & $\begin{array}{c}\text { Herbaceous Vegetation Height }+\% \\
\text { Rock Cover }+ \text { CV Height }+ \text { Shrub } \\
\text { Presence }\end{array}$ & 67.853 & 7 & 72.084 & 2.779 \\
\hline 3 & SuiTable 2 & $\begin{array}{l}\text { Herbaceous Vegetation Height }+\% \\
\text { Rock Cover }+ \text { CV Height }+ \text { Slope }\end{array}$ & 68.630 & 6 & 72.861 & 3.556 \\
\hline 4 & SuiTable 3 & $\begin{array}{l}\text { Herbaceous Vegetation Height }+\% \\
\text { Rock Cover }+ \text { CV Height }+ \text { Aspect }\end{array}$ & 68.852 & 6 & 73.083 & 3.778 \\
\hline 5 & SuiTable 4 & $\begin{array}{l}\text { Herbaceous Vegetation Height }+\% \\
\text { Rock Cover + CV Height + Altitude }\end{array}$ & 69.004 & 6 & 73.235 & 3.930 \\
\hline 6 & UnsuiTable 1 & $\begin{array}{c}\text { Herbaceous Vegetation Height }+\% \\
\text { Rock Cover }+ \text { CV Height }+ \text { Slope }+ \\
\text { Shrub Presence }\end{array}$ & 71.311 & 8 & 75.546 & 6.241 \\
\hline 7 & UnsuiTable 2 & $\begin{array}{c}\text { Herbaceous Vegetation Height }+\% \\
\text { Rock Cover + CV Height }+ \text { Aspect }+ \\
\text { Shrub Presence }\end{array}$ & 71.614 & 8 & 75.850 & 6.545 \\
\hline 8 & UnsuiTable 3 & $\begin{array}{c}\text { Herbaceous Vegetation Height }+\% \\
\text { Rock Cover }+ \text { CV Height }+ \text { Altitude }+ \\
\text { Shrub Presence }\end{array}$ & 71.726 & 8 & 75.962 & 6.657 \\
\hline 9 & UnsuiTable 4 & $\begin{array}{c}\text { Herbaceous Vegetation Height }+\% \\
\text { Rock Cover }+ \text { CV Height }+ \text { Slope }+ \\
\text { Aspect }\end{array}$ & 72.387 & 7 & 76.623 & 7.318 \\
\hline
\end{tabular}


Table 5. Cont.

\begin{tabular}{|c|c|c|c|c|c|c|}
\hline Model Rank & Model Name & Explanatory Variables & Deviance & $\mathbf{K}$ & $\mathrm{AIC}_{\mathrm{C}}$ & $\Delta \mathrm{AIC}_{\mathrm{C}}$ \\
\hline 10 & UnsuiTable 5 & $\begin{array}{c}\text { Herbaceous Vegetation Height }+\% \\
\text { Rock Cover }+ \text { CV Height }+ \text { Altitude }+ \\
\text { Slope }\end{array}$ & 72.540 & & 76.775 & 7.470 \\
\hline 11 & UnsuiTable 6 & $\begin{array}{c}\text { Herbaceous Vegetation Height }+\% \\
\text { Rock Cover }+ \text { CV Height }+ \text { Altitude }+ \\
\text { Aspect }\end{array}$ & 72.763 & 7 & 76.999 & 7.694 \\
\hline \multirow[t]{3}{*}{12} & $\begin{array}{c}\text { Maximal/ } \\
\text { UnsuiTable } 7\end{array}$ & $\begin{array}{l}\text { Herbaceous Vegetation Height }+\% \\
\text { Rock Cover }+ \text { CV Height }+ \text { Altitude }+ \\
\text { Slope }+ \text { Aspect }+ \text { Shrub Presence }\end{array}$ & 78.895 & 10 & 83.140 & 13.835 \\
\hline & & Best Model & Estimate & S.E. & $t$ & $p$-Value \\
\hline & & $\begin{array}{c}\text { Intercept } \\
\text { Herbaceous Vegetation Height } \\
\text { \% Rock Cover } \\
\text { CV Height }\end{array}$ & $\begin{array}{c}1.410 \\
-0.197 \\
0.140 \\
-0.006\end{array}$ & $\begin{array}{l}0.259 \\
0.050 \\
0.049 \\
0.002\end{array}$ & $\begin{array}{c}5.435 \\
-3.941 \\
2.847 \\
-3.124\end{array}$ & $\begin{array}{c}<0.001 \\
<0.001 \\
0.006 \\
0.003\end{array}$ \\
\hline
\end{tabular}

\subsection{Investigation of Beta Diversity}

The MRPP analysis showed that bird communities were significantly different between the three grazing regimes $(\mathrm{T}=-14.23, \mathrm{~A}=0.22, p<0.001)$. Also, significant differences were observed among each pair of grazing regime. Specifically, the greater bird community separation observed among NGG and HGG $(\mathrm{T}=-15.41, \mathrm{~A}=0.26, p<0.001)$, followed by bird communities among the NGG and LGG $(\mathrm{T}=-10.41, \mathrm{~A}=0.19, p<0.001)$, while bird communities among LGG and HGG showed little separation $(\mathrm{T}=-4.35, \mathrm{~A}=0.06$, $p=0.001$.

The grassland preferred by different bird species is presented in (Table 6). The ISA showed that nine bird species were consistent in one of the three grazing regimes $(p<0.05)$. Specifically, the NGG was preferred by the Corn Bunting and the Rock Bunting, the LGG was preferred by the Tawny Pipit, whereas the HGG was preferred by the Eurasian Skylark, the Northern Wheatear, the Whinchat, the Linnet, the Woodlark, and the Yellowhammer.

Table 6. Results of the Indicator Species Analysis. Monte Carlo test of significance of observed maximum indicator value (IV) for each bird species, based on 1000 randomizations. The means and SD of the IV from randomizations are given along with $p$-values for the hypothesis of no difference between groups. Significant indicator species are presented in bold. Within parenthesis, the most important grazing regime (1: NGG; 2: LGG; 3: HGG) that is associated with each bird species are presented.

\begin{tabular}{|c|c|c|c|c|c|}
\hline Common Name & Scientific Name & Code & $\begin{array}{c}\text { Observed } \\
\text { Indicator Value } \\
\text { (IV) }\end{array}$ & $\begin{array}{c}\text { IV from } \\
\text { Randomized } \\
\text { Groups }\end{array}$ & $p$-Value \\
\hline Eurasian Skylark & Alauda arvensis & Alaarv & 60 & $27.3 \pm 4.56$ & $0.001(3)$ \\
\hline Rock Partridge & Alectoris graeca & Alegra & 13.3 & $9.9 \pm 4.32$ & $0.228(1)$ \\
\hline Tawny Pipit & Anthus campestris & Antcam & 23.3 & $10.7 \pm 4.35$ & $0.035(2)$ \\
\hline Water Pipit & Anthus spinoletta & Antspi & 5 & $5 \pm 0.16$ & $1(3)$ \\
\hline Tree Pipit & Anthus trivialis & Anttri & 21.1 & $16 \pm 4.76$ & $0.163(3)$ \\
\hline Common Quail & Coturnix coturnix & Cotcot & 15 & $14.6 \pm 4.58$ & $0.443(1)$ \\
\hline Corn Bunting & Emberiza calandra & Embcal & 21.8 & $10.6 \pm 4.44$ & $0.031(1)$ \\
\hline Rock Bunting & Emberiza cia & Embcia & 35 & $9.8 \pm 4.13$ & $0.001(1)$ \\
\hline Cirl Bunting & Emberiza cirlus & Embcir & 5 & $5 \pm 0.16$ & $1(2)$ \\
\hline Yellowhammer & Emberiza citrinella & Embcit & 38.1 & $12.6 \pm 4.50$ & $0.001(3)$ \\
\hline Ortolan Bunting & Emberiza hortulana & Embhor & 19.8 & $15.9 \pm 4.99$ & $0.223(1)$ \\
\hline Red-backed Shrike & Lanius collurio & Lancol & 23.8 & $19.1 \pm 4.81$ & $0.162(1)$ \\
\hline Common Linnet & Linaria cannabina & Lincan & 30 & $15.2 \pm 5.24$ & $0.016(3)$ \\
\hline Woodlark & Lullula arborea & Lularb & 22.5 & $10.3 \pm 4.33$ & $0.043(3)$ \\
\hline Rufous-tailed Rock Thrush & Monticola saxatilis & Monsax & 13.1 & $13.8 \pm 4.38$ & $0.571(3)$ \\
\hline
\end{tabular}


Table 6. Cont.

\begin{tabular}{|c|c|c|c|c|c|}
\hline Common Name & Scientific Name & Code & $\begin{array}{c}\text { Observed } \\
\text { Indicator Value } \\
\text { (IV) }\end{array}$ & $\begin{array}{l}\text { IV from } \\
\text { Randomized } \\
\text { Groups }\end{array}$ & $p$-Value \\
\hline Northern Wheatear & Oenanthe oenanthe & Oenoen & 40 & $24 \pm 5.16$ & $0.013(3)$ \\
\hline Great Tit & Parus major & Parmaj & 10 & $4.8 \pm 3.48$ & $0.313(1)$ \\
\hline Black Redstart & Phoenicurus ochruros & Phooch & 5 & $5 \pm 0.16$ & $1(2)$ \\
\hline Common Chiffchaff & Phylloscopus collybita & Phycol & 5 & $5 \pm 0.16$ & $1(3)$ \\
\hline Whinchat & Saxicola rubetra & Saxrub & 48 & $15.8 \pm 4.66$ & $0.001(3)$ \\
\hline Common Stonechat & Saxicola torquatus & Saxtor & 5 & $6.6 \pm 3.46$ & $0.783(1)$ \\
\hline European Serin & Serinus serinus & Serser & 5 & $5 \pm 0.16$ & $1(2)$ \\
\hline Lesser Whitethroat & Sylvia curruca & Sylcur & 5 & $5 \pm 0.16$ & $1(3)$ \\
\hline Eurasian Blackbird & Turdus merula & Turmer & 5 & $5 \pm 0.16$ & $1(3)$ \\
\hline Mistle Thrush & Turdus viscivorus & Turvis & 11.2 & $7.1 \pm 3.65$ & $0.287(1)$ \\
\hline
\end{tabular}

\subsection{Investigation of Gamma Diversity}

The NMS applied to the matrix of the 25 grassland bird species. A final optimal three-dimensional ordination space was acceptable for the representation of bird species composition of the three grazing regimes (stress $=18.81 \%$ ) and explained $73 \%$ of the variance in the data (Table 6). We plotted joint plots of sample scores and bird species scores using all three axes, which explained $16.2 \%, 10.1 \%$ and $46.8 \%$ variance of the data, respectively (Table 7). Out of the nine environmental and topographic variables used, only the mean herbaceous vegetation height was correlated with the three-dimension species space axes. The mean herbaceous vegetation height was negatively associated with NMS axes 3. A graphical overlay of habitat on the ordination of sample scores distinguished census plots in NGG from LGG and/or HGG (Figure 2a). Furthermore, the ordination of census plots with and without shrubs showed that NGG presented shrub presence in the majority of sample plots against those in LGG and HGG (Figure 2b). According to Figure 2, the Rock Bunting, the Corn Bunting, the Ortolan Bunting, the Stonechat, the Great Tit and the Red-backed Shrike where positively associated with herbaceous vegetation height. In contrast, the Yellowhammer, the Skylark, the Whinchat, the Linnet, the Cirl Bunting and the Serin were negatively associated with herbaceous vegetation height. Shrubs were present mainly in the NGG and LGG and attracted species like the Great Tit, Corn Bunting, the Rock Bunting, the Cirl Bunting, and the Serin.

Table 7. Proportion of variance represented by the final three axes of the Non-metric Multidimensional Scaling (NMS) ordination plots of the birds occurring in the three studied grasslands and the Pearson correlation coefficients of the 9 habitat and topographic variables with each axis.

\begin{tabular}{cccc}
\hline & Axis 1 & Axis 2 & Axis 3 \\
\hline Variance Represented $\left(r^{2}\right)$ & & & \\
Increment & 0.162 & 0.101 & 0.468 \\
Cumulative & 0.162 & 0.263 & 0.730 \\
Correlation with NMS Axis $(r)$ & & & \\
\% Herbaceous Vegetation Cover & -0.019 & 0.177 & 0.170 \\
\% Rock Cover & 0.267 & -0.039 & -0.054 \\
\% Bare Ground Cover & -0.048 & 0.084 & 0.086 \\
\% Fern Cover & -0.238 & -0.143 & -0.100 \\
Herbaceous Vegetation Height & 0.004 & 0.259 & -0.654 \\
CV Herbaceous Vegetation Height & 0.298 & -0.262 & 0.289 \\
Altitude & 0.156 & 0.020 & 0.440 \\
Slope & 0.311 & -0.027 & -0.362 \\
Aspect & -0.017 & -0.030 & 0.032 \\
\hline
\end{tabular}




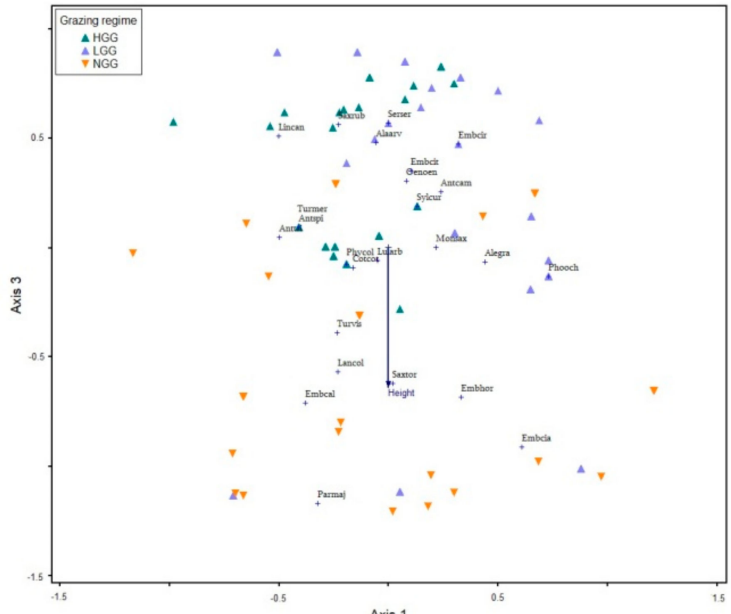

(a)

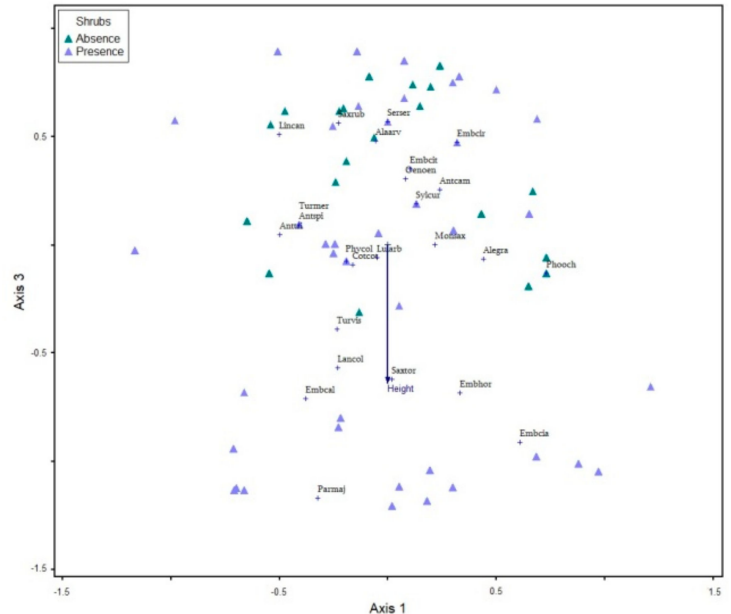

(b)

Figure 2. Non-metric Multidimensional Scaling (NMS) ordination jointplots of sample scores, species scores and habitat variables on grasslands with (a) different grazing intensity (NGG: non-grazed grassland, LGG: low grazing intensity grassland, HGG: high grazing intensity grassland) and (b) shrub presence/absence. Definitions of habitat variables; Height: Herbaceous vegetation height. See Table 7 for NMS summary statistics and Table 6 for definitions of species codes.

\section{Discussion}

Avian communities were surveyed in representative pseudo-alpine grassland ecosystems of the South Pindos Mountains in central Greece. These grasslands were located above the tree line and selected according to the different levels of grazing transhumant livestock. Significant differences were found among the surveyed grasslands in regard to vegetation structure and the topography. Herbaceous vegetation height, heterogeneity of vegetation height and percent of rock cover were the key environmental variables that influenced bird species composition in the three grasslands. Our results indicate that there is a significant difference in the bird communities among the three studied grasslands. This is evident in the different bird species present in the three grasslands as well as in the differences of their diversity indicators $\left(\mathrm{S}_{\text {mean }}, \mathrm{A}, \mathrm{H}_{\text {mean }}^{\prime} \mathrm{S}, \mathrm{WS}, \mathrm{H}^{\prime}, E_{\text {var }}\right)$.

The differences in the vegetation structure of the grasslands would appear to mainly be a result of different levels of grazing transhumant livestock, which consequently affected the bird communities. Given that our findings are based on the interviews of the shepherds and the counting of their herds, the results from the analyses concerning the effects of grazing intensity should be treated with caution. Further experimental investigation is needed to estimate the grazing intensity by taking into account the possible impact of wild herbivores. In the lower altitude subalpine forests neighbor to our study grasslands, occur Roe Deers (Capreolus capreolus), which are selective solitary browsers and probably use the grasslands as feeding grounds. Therefore, future studies should deal with the estimation of grazing intensity through the counting of dung [59] of both livestock and wild herbivores in the pseudo-alpine grasslands. Also, differences in the interaction between soil nutrients and grazing may affect the vegetation structure of grasslands. It has been reported that heavy grazing reduces the herbaceous vegetation and soil nutrients because herbivores compress the soil, remove the vegetation biomass and as a result they reduce the amount of litter on the soil [60]. Vegetation height was higher in NGG followed by LGG and HGG, while the heterogeneity of vegetation height was higher in LGG, followed by the NGG and the HGG.

Interestingly, our results showed that bird species richness and bird diversity (alpha diversity) were affected only by the environmental and not by the topographic variables. Specific variations in the environmental characteristics, such as the difference in recorded vegetation height, vegetation height heterogeneity and rock cover were demonstrated to determine differences in bird species composition among the studied grasslands. Bird 
species richness and bird diversity corresponded positively to a decrease of vegetation height and vegetation height heterogeneity and to an increase of the percentage of rock cover. Vegetation height has been the main factor associated with avian diversity and composition in grasslands [61,62]. This difference in vegetation height demonstrates the importance of grassland mosaics with vegetation of different heights for grassland bird diversity. The analysis of gamma diversity in our study area showed that many grassland birds require a mosaic landscape with different habitat patches to satisfy their breeding demands and to improve their foraging conditions [35]. Grazing increases the structural diversity and constructs variable microhabitats for a great proportion of species $[3,17,63]$. The relatively low vegetation height derived from the seasonal grazing probably improved the nesting and foraging conditions for grassland species [16,21]. Transhumance grazing holds vegetation height relatively low thus increasing food accessibility [64,65], locomotion on the ground and offering higher efficiency in predator detection [66]. Moreover, presence of livestock dung may increase the available invertebrates [67], which in turn may attract valuable numbers of birds. Also, the presence of rocks on those high-altitude grasslands attracts rock dueling species, which nest among the boulders and forage on the grazed areas thus increasing the total species diversity. The presence of shrubs may also have ambivalent effects on grassland birds. A study conducted in arctic riparian plains in Norway showed that intense grazing by Reindeers led to shrub loss which affected negatively both shrub and open associated bird species [18]. This trend is probably associated with the decrease of nest and cover habitat, and insects, which are a primary food source for many species [18,68].

Avian communities are affected by the presence of transhumant livestock in the pseudo-alpine grassland ecosystems of South Pindos Mountains through the differences in vegetation structure. Bird communities among the two grazed grasslands (LGG and HGG) showed a lower separation than the communities between the two grazed (LGG and HGG) and the non-grazed (NGG) one. Transhumance is highlighted as an ecological management technique that shapes and maintains stable and dynamic the upland grasslands, while overcoming the plethora of ecological problems derived by intensive, sedentary livestock activities in high altitude ecosystems $[8,10]$. The seasonal exploitation of grasslands, the local livestock breeds that have adapted to the special conditions of the uplands and the shepherding exert low pressure on grasslands hence improves the nesting and foraging conditions for the threatened pseudo-alpine avifauna. A pan-European review and metaanalysis showed that the traditional practices and short-term abandonment of grazing are of high importance for the enhancement of richness and diversity [14]. Compared to high intensity grazing, these low intensity systems resulted in higher richness and diversity. Furthermore, traditionally grazed grasslands were richer in arthropods than overgrazed; arthropods compose the diet for the majority of bird species inhabiting high altitude grasslands. However, the high intensity grazing was shown to benefit open habitat species due to the prevention of woody vegetation encroachment [14]. Additionally, the short-term abandonment was shown to have similar positive effect on biodiversity. As a result, the pausing of grazing for longer periods may enhance the encroachment of woody vegetation and affect negatively the open habitat species [14].

The majority of birds inhibiting the studied pseudo-alpine grasslands are grounddwelling species (Table A1). The low vegetation height of the HGG was reflected by the greater number of indicator bird species (6) compared to the LGG (1) and NGG (2). The presence of two indicator species in NGG which are under conservation status also highlights the importance of no grazing areas. The Eurasian Skylark, the Yellowhammer, the Whinchat, the Woodlark, the Linnet, and the Northern Wheatear which are SPEC, showed great preferences for highly grazed grasslands. The Eurasian Skylark, a typical ground-associated grassland bird, showed a positive response to transhumance. Eurasian Skylarks avoid tall and dense vegetation $[49,69]$ due to the difficulties they face in foraging and movement. Higher grazing pressure leads to highly exploited areas with low vegetation height and vertical structure, but favoring feeding opportunities in many birds by making food easy to access. Furthermore, the Yellowhammer and the Whinchat, two upland species 
highly associated to open areas and especially grasslands in Greece [70], were positively affected by grazing due to their requirements for low herbaceous vegetation height. In our study area both species were absent from NGG and their higher concentrations were observed on HGG, indicating a positive effect of grazing on their numbers. A similar response was observed in the Woodlark, a species that prefers grazed pastures in order to benefit by low vegetation for breeding and foraging. Moreover, rock presence in grasslands is responsible for the occurrence of rock-dwelling species, hence it increases the number of species present. The Northern Wheatear is a typical species of stony high-altitude grasslands. It needs areas of low vegetation in order to feed [71], and fallen rocks, boulders, and screes as nesting locations [72], hence the combination of grazed sites with rocky areas favored the occurrence of the species in high grazing intensity pastures. On the other hand, only one bird species of high conservation value, the Tawny Pipit, was found to benefit from low grazing pressure in our study. The Tawny Pipit highly concentrated in LGG, resembling the habitat preferences of the species for high altitude stony pastures. The presence of a low number of small ruminants creates a heterogeneous vegetation mosaic with areas of low and tall herbaceous vegetation, which offers suitable foraging and nesting sites for the species respectively [73]. Bird community in NGG showed a great separation from those in both grazed grasslands with two species, the Rock and the Corn Bunting, highly confined to those areas. The Rock Bunting was observed only in NGG and was probably favored by the presence of shrubs and the rock cover, which are important territory components of the species [74]. Moreover, the Corn Bunting seemed to benefit from the presence of shrubs $[75,76]$ in grasslands with absence of grazing.

Grassland bird species show different susceptibility to grazing disturbance $[35,44,77]$. Our results demonstrate a separation of species between areas, bird species recorded in the NGG that depend on tall grass and shrubs were replaced by species associated with short grass in grazed grasslands. Specific management practices can satisfy the nesting and foraging requirements of a group of species, but cannot benefit others $[35,78]$. Areas with low or no grazing are necessary to ensure viable populations of tall grass $[14,35,79]$ and shrub associated species [14]. On the other hand, in grazed grasslands, a short grass assemblage of birds is benefited [35,77]. Our results demonstrate that presence of both grazed and non-grazed grassland areas is essential for the conservation of the pseudo-alpine grassland birds as also observer by Isacch and Cardoni [79]. Moreover, some researchers have proposed that some areas should not be managed, for obtaining the maximum diversity of grassland birds [35,78]. Thus, this habitat heterogeneity is necessary to ensure species coexistence and maintain the highest diversity of grassland bird communities [18,35,62,80,81].

However, we are aware that our research may have some limitations. The first is that it is a single-year study and offers no long-term results on the effects of pastoral activities on bird communities. The second is the small number of survey points as a consequence of the small area and the harsh terrain of the grasslands under study, and the third is the absence of replicate sites of the NGG, LGG, and HGG.

\section{Conclusions}

This paper has highlighted the importance of the different levels of grazing transhumant livestock and managed to give a thorough insight on the effects of this particular stock rearing system on the avian communities of high-altitude grasslands. Grazed grasslands were richest in birds, and favored a higher number of bird species of conservation concern than the non-grazed. Breeding and foraging grassland birds responded positively to low vegetation height, to vegetation height heterogeneity, and to the increased rock cover. Moreover, our research underlined that transhumance favored the short grass breeding avifauna, while the decline of transhumance and the abandonment of pseudo-alpine grasslands may alter those ecosystems in benefit of tall grass and shrub associated bird species. This study has gone some way towards enhancing our understanding of the importance of transhumance for wildlife conservation, so conservationists and managers 
of natural resources should reinforce the existence of grazed (managed) and ungrazed (unmanaged) areas under the traditional transhumance in order to maintain highly diverse avian communities on the pseudo-alpine grassland ecosystems.

Author Contributions: Conceptualization, E.G.K. and D.E.B.; methodology, E.G.K. and D.E.B.; validation, all; formal analysis, E.G.K.; investigation, E.G.K.; resources, E.G.K. and D.E.B.; data curation, E.G.K. and D.E.B.; writing—original draft preparation, E.G.K.; writing—review and editing, D.E.B., C.G.V., E.M.A., and V.G.; supervision, D.E.B. All authors have read and agreed to the published version of the manuscript.

Funding: This research received no external funding.

Institutional Review Board Statement: Not applicable.

Informed Consent Statement: Not applicable.

Data Availability Statement: The data presented in this study are available on request from the corresponding author.

Acknowledgments: We wish to thank Georgios Kotsonas, Christos Karras and Ioannis Katsaros who provided assistance in the field and the shepherds who gave us valuable information concerning their stock rearing practices. We are also thanking Grigorios Kavvadias and Elisavet Dimou for their linguistic assistance on the final draft of this manuscript. We are most grateful to Jukka Jokimäki for his insightful suggestions and support, and the two anonymous reviewers for their beneficial inputs. The authors declare that the experiments comply with the Greek and EU laws.

Conflicts of Interest: The authors declare no conflict of interest.

\section{Appendix A}

Nesting and foraging substrate (G: ground, R: rock, S: shrub, T: tree) of the 25 bird species recorded in pseudo-alpine grasslands under different grazing regime during the breeding season of 2016 in Pindos Mountains, Central Greece.

Table A1. Nesting and foraging substrate (G: ground, R: rock, S: shrub, T: tree) of the 25 bird species recorded in our study area.

\begin{tabular}{|c|c|c|c|c|}
\hline Common Name & Scientific Name & Nesting Substrate & Foraging Substrate & Reference \\
\hline Eurasian Skylark & Alauda arvensis & $\mathrm{G}$ & G & [82] \\
\hline Rock Partridge & Alectoris graeca & $\mathrm{R}, \mathrm{G}$ & G & [83] \\
\hline Tawny Pipit & Anthus campestris & G & G & [82] \\
\hline Water Pipit & Anthus spinoletta & G & G & [82] \\
\hline Tree Pipit & Anthus trivialis & G & $\mathrm{G}$ & [82] \\
\hline Common Quail & Coturnix coturnix & $\mathrm{G}$ & G & [83] \\
\hline Corn Bunting & Emberiza calandra & $\mathrm{G}, \mathrm{S}$ & $\mathrm{G}$ & [84] \\
\hline Rock Bunting & Emberiza cia & $G, R, S$ & $G, S$ & [84] \\
\hline Cirl Bunting & Emberiza cirlus & $\mathrm{G}, \mathrm{S}, \mathrm{T}$ & $\mathrm{G}, \mathrm{T}$ & {$[84]$} \\
\hline Yellowhammer & Emberiza citrinella & $\mathrm{G}, \mathrm{S}$ & G & [84] \\
\hline Ortolan Bunting & Emberiza hortulana & $\mathrm{G}, \mathrm{R}$ & $\mathrm{G}, \mathrm{S}$ & [84] \\
\hline Red-backed Shrike & Lanius collurio & $\mathrm{S}, \mathrm{T}$ & $\mathrm{G}, \mathrm{S}$ & [85] \\
\hline Common Linnet & Linaria cannabina & $S, R, G, T$ & $\mathrm{G}, \mathrm{S}$ & [86] \\
\hline Woodlark & Lullula arborea & $G$ & $\mathrm{G}$ & [82] \\
\hline Rufous-tailed Rock Thrush & Monticola saxatilis & $\mathrm{R}$ & $\mathrm{G}$ & [82] \\
\hline Northern Wheatear & Oenanthe oenanthe & $\mathrm{G}, \mathrm{R}$ & G & {$[82]$} \\
\hline Great Tit & Parus major & $\mathrm{T}$ & $\mathrm{T}, \mathrm{S}, \mathrm{G}$ & [85] \\
\hline Black Redstart & Phoenicurus ochruros & $\mathrm{R}$ & G & [82] \\
\hline Common Chiffchaff & Phylloscopus collybita & $\mathrm{G}, \mathrm{S}, \mathrm{T}$ & $\mathrm{T}, \mathrm{S}$ & [87] \\
\hline Whinchat & Saxicola rubetra & G & G & [82] \\
\hline Common Stonechat & Saxicola torquatus & G & G & [82] \\
\hline European Serin & Serinus serinus & $\mathrm{T}, \mathrm{S}$ & $\mathrm{T}, \mathrm{S}, \mathrm{G}$ & [86] \\
\hline Lesser Whitethroat & Sylvia curruca & S & $\mathrm{S}$ & [87] \\
\hline Eurasian Blackbird & Turdus merula & $\mathrm{T}, \mathrm{S}, \mathrm{G}$ & $\mathrm{G}, \mathrm{S}$ & [82] \\
\hline Mistle Thrush & Turdus viscivorus & $\mathrm{T}, \mathrm{R}$ & $\mathrm{G}, \mathrm{T}$ & [82] \\
\hline
\end{tabular}




\section{References}

1. De Aranzabal, I.; Schmitz, M.F.; Aguilera, P.; Pineda, F.D. Modelling of landscape changes derived from the dynamics of socio-ecological systems. A case of study in a semiarid Mediterranean landscape. Ecol. Indic. 2008, 8, 672-685. [CrossRef]

2. Atauri, J.A.; De Lucio, J.V. The role of landscape structure in species richness distribution of birds, amphibians, reptiles and lepidopterans in Mediterranean landscapes. Landsc. Ecol. 2001, 16, 147-159. [CrossRef]

3. Bakaloudis, D.E. Livestock grazing, openings and raptors conservation in the Dadia-Lefkimi-Soufli Forest National Park. Opt. Méditerr. Ser. A Mediterr. Semin. 2016, 114, 437-440.

4. Raven, P.H. Presidential address: Science, sustainability, and the human prospect. Science 2002, 297, 954-958. [CrossRef] [PubMed]

5. Valamoti, S.M. Detecting seasonal movement from animal dung: An investigation in Neolithic northern Greece. Antiquity 2007, 81, 1053-1064. [CrossRef]

6. Ruíz, M.; Ruíz, J.P. Ecological history of transhumance in Spain. Biol. Conserv. 1986, 37, 73-86. [CrossRef]

7. Blondel, J.; Aronson, J.; Bodiou, J.-Y.; Boeuf, G. The Mediterraneaen Region-Biological Diversity in Space and Time; Oxford University Press: Oxford, UK, 2010; ISBN 0-19-955798-5.

8. Fernández-Giménez, M.E.; Estaque, F.F. Pyrenean pastoralists' ecological knowledge: Documentation and application to natural resource management and adaptation. Hum. Ecol. 2012, 40, 287-300. [CrossRef]

9. Koocheki, A.; Gliessman, S.R. Pastoral nomadism, a sustainable system for grazing land management in arid areas. J. Sustain. Agric. 2005, 25, 113-131. [CrossRef]

10. Bignal, E.M. Transhumance in Spain. In Birds and Pastoral Agriculture in Europe; Curtis, E.M., Curtis, M.A., Eds.; Joint Nature Conservation Committee: London, UK, 1991; pp. 18-21.

11. Evans, D.M.; Redpath, S.M.; Elston, D.A.; Evans, S.A.; Mitchell, R.J.; Dennis, P. To graze or not to graze? Sheep, voles, forestry and nature conservation in the British uplands. J. Appl. Ecol. 2006, 43, 499-505. [CrossRef]

12. Krausman, P.R.; Naugle, D.E.; Frisina, M.R.; Northrup, R.; Bleich, V.C.; Block, W.M.; Wallace, M.C.; Wright, J.D. Livestock grazing, wildlife habitat, and rangeland values. Rangelands 2009, 31, 15-19. [CrossRef]

13. Metera, E.; Sakowski, T.; Słoniewski, K.; Romanowicz, B. Grazing as a tool to maintain biodiversity of grassland-A review. Anim. Sci. Pap. Rep. 2010, 28, 315-334.

14. Sartorello, Y.; Pastorino, A.; Bogliani, G.; Ghidotti, S.; Viterbi, R.; Cerrato, C. The impact of pastoral activities on animal biodiversity in Europe: A systematic review and meta-analysis. J. Nat. Conserv. 2020, 56. [CrossRef]

15. Pöyry, J.; Lindgren, S.; Salminen, J.; Kuussaari, M. Restoration of butterfly and moth communities in semi-natural grasslands by cattle grazing. Ecol. Appl. 2004, 14, 1656-1670. [CrossRef]

16. Walk, J.W.; Warner, R.E. Grassland management for the conservation of songbirds in the Midwestern USA. Biol. Conserv. 2000, 94, 165-172. [CrossRef]

17. Buckingham, D.L.; Brook, A.J.; Eschen, R.; Maczey, N.; Wheeler, K.; Peach, W.J. Integrating biodiversity conservation with grassland farming: Extensive cattle grazing and farmland birds. In EGF at 50: The future of European grasslands, Proceedings of the 25th General Meeting of the European Grassland Federation, Aberystwyth, Wales, UK, 7-11 September 2014; Hopkins, A., Collins, R.P., Fraser, M.D., King, V.R., Lloyd, D.C., Moorby, J.M., Robson, P.R.H., Eds.; IBERS, Aberystwyth University: Gogerddan, UK, 2015; pp. 236-238.

18. Ims, R.A.; Henden, J.A. Collapse of an arctic bird community resulting from ungulate-induced loss of erect shrubs. Biol. Conserv. 2012, 149, 2-5. [CrossRef]

19. Soloviev, M.Y.; Tomkovich, P.S. Bird breeding conditions in the Arctic in 2005. Arct. Birds 2006, 8, $27-32$.

20. Zöckler, C.; Miles, L.; Fish, L.; Wolf, A.; Rees, G.; Danks, F. Potential impact of climate change and reindeer density on tundra indicator species in the Barents Sea region. Clim. Chang. 2008, 87, 119-130. [CrossRef]

21. Loe, L.E.; Mysterud, A.; Stien, A.; Steen, H.; Evans, D.M.; Austrheim, G. Positive short-term effects of sheep grazing on the alpine avifauna. Biol. Lett. 2007, 3, 109-111. [CrossRef]

22. Tichit, M.; Renault, O.; Potter, T. Grazing regime as a tool to assess positive side effects of livestock farming systems on wading birds. Livest. Prod. Sci. 2005, 96, 109-117. [CrossRef]

23. Faria, N.; Rabaça, J.E.; Morales, M.B. The importance of grazing regime in the provision of breeding habitat for grassland birds: The case of the endangered little bustard (Tetrax tetrax). J. Nat. Conserv. 2012, 20, 211-218. [CrossRef]

24. Söderström, B.; Pärt, T.; Linnarsson, E. Grazing effects on between-year variation of farmland bird communities. Ecol. Appl. 2001, 11, 1141-1150. [CrossRef]

25. Davies, K.F.; Melbourne, B.A.; James, C.D.; Cunningham, R.B. Using traits of species to understand responses to land use change: Birds and livestock grazing in the Australian arid zone. Biol. Conserv. 2010, 143, 78-85. [CrossRef]

26. Cody, M.L. Habitat selection in grassland and open-country birds. In Habitat Selection in Birds; Cody, M.L., Ed.; Academic Press: Orlando, FL, USA, 1985; pp. 191-226.

27. Martin, T.G.; Possingham, H.P. Predicting the impact of livestock grazing on birds using foraging height data. J. Appl. Ecol. 2005, 42, 400-408. [CrossRef]

28. Coppedge, B.R.; Fuhlendorf, S.D.; Harrell, W.C.; Engle, D.M. Avian community response to vegetation and structural features in grasslands managed with fire and grazing. Biol. Conserv. 2008, 141, 1196-1203. [CrossRef]

29. Foster, C.N.; Barton, P.S.; Lindenmayer, D.B. Effects of large native herbivores on other animals. J. Appl. Ecol. 2014, 51, 929-938. [CrossRef] 
30. Reino, L.; Porto, M.; Morgado, R.; Moreira, F.; Fabião, A.; Santana, J.; Delgado, A.; Gordinho, L.; Cal, J.; Beja, P. Effects of changed grazing regimes and habitat fragmentation on Mediterranean grassland birds. Agric. Ecosyst. Environ. 2010, 138, 27-34. [CrossRef]

31. Golding, J.D.; Dreitz, V.J. Songbird response to rest rotation and season-long cattle grazing in grassland sagebrush ecosystem. J. Environ. Manag. 2017, 204, 605-612. [CrossRef]

32. Rook, A.J.; Dumont, B.; Isselstein, J.; Osoro, K.; Wallis De Vries, M.F.; Parente, G.; Mills, J. Matching type of livestock to desired biodiversity outcomes in pastures-A review. Biol. Conserv. 2004, 119, 137-150. [CrossRef]

33. Henderson, I.G.; Fuller, R.J.; Conway, G.J.; Gough, S.J. Evidence for declines in populations of grassland-associated birds in marginal upland areas of Britain. Bird Study 2004, 51, 12-19. [CrossRef]

34. Fuhlendorf, S.D.; Harreli, W.C.; Engle, D.M.; Hamilton, R.G.; Davis, C.A.; Leslie, D.M. Should heterogeneity be the basis for conservation? Grassland bird response to fire and grazing. Ecol. Appl. 2006, 16, 1706-1716. [CrossRef]

35. Jacoboski, L.I.; Paulsen, R.K.; Hartz, S.M. Bird-grassland associations in protected and non-protected areas in southern Brazil. Perspect. Ecol. Conserv. 2017, 15, 109-114. [CrossRef]

36. Langlands, P.R.; Brennan, K.E.C.; Framenau, V.W.; Main, B.Y. Predicting the post-fire responses of animal assemblages: Testing a trait-based approach using spiders. J. Anim. Ecol. 2011, 80, 558-568. [CrossRef] [PubMed]

37. MacDonald, D.; Crabtree, J.R.; Wiesinger, G.; Dax, T.; Stamou, N.; Fleury, P.; Gutierrez Lazpita, J.; Gibon, A. Agricultural abandonment in mountain areas of Europe: Environmental consequences and policy response. J. Environ. Manag. 2000, 59, 47-69. [CrossRef]

38. Geri, F.; Amici, V.; Rocchini, D. Human activity impact on the heterogeneity of a Mediterranean landscape. Appl. Geogr. 2010, 30, 370-379. [CrossRef]

39. Moreira, F.; Russo, D. Modelling the impact of agricultural abandonment and wildfires on vertebrate diversity in Mediterranean Europe. Landsc. Ecol. 2007, 22, 1461-1476. [CrossRef]

40. Chapin, F.S., III; Zavaleta, E.S.; Eviner, V.T.; Naylor, R.L.; Vitousek, P.M.; Reynolds, H.L.; Hooper, D.U.; Lavorel, S.; Sala, O.E.; Hobbie, S.E. Consequences of changing biodiversity. Nature 2000, 405, 234-242. [CrossRef]

41. Woinarski, J.C.Z.; Burbidge, A.A.; Harrison, P.L. Ongoing unraveling of a continental fauna: Decline and extinction of Australian mammals since European settlement. Proc. Natl. Acad. Sci. USA 2015, 112, 4531-4540. [CrossRef] [PubMed]

42. Körner, C. The Alpine life zone under global change. Gayana. Botánica 2000, 57, 1-17. [CrossRef]

43. Patthey, P.; Wirthner, S.; Signorell, N.; Arlettaz, R. Impact of outdoor winter sports on the abundance of a key indicator species of alpine ecosystems. J. Appl. Ecol. 2008, 45, 1704-1711. [CrossRef]

44. Svensson, S. Species composition and population fluctuations of alpine bird communities during 38 years in the Scandinavian mountain range. Ornis Svec. 2006, 16, 183-210.

45. Oteros-Rozas, E.; Ontillera-Sánchez, R.; Sanosa, P.; Gómez-Baggethun, E.; Reyes-García, V.; González, J.A. Traditional ecological knowledge among transhumant pastoralists in Mediterranean Spain. Ecol. Soc. 2013, 18, 33. [CrossRef]

46. Sidiropoulou, A.; Karatassiou, M.; Galidaki, G.; Sklavou, P. Landscape pattern changes in response to transhumance abandonment on mountain Vermio (North Greece). Sustainability 2015, 7, 15652-15673. [CrossRef]

47. Bibby, C.; Burgess, N.; Hill, D.; Mustoe, S. Bird Census Techniques, 2nd ed.; Academic Press: London, UK, $2000 ;$ p. 302.

48. Fuller, R.J.; Langslow, D.R. Estimating numbers of birds by point counts: How long should counts last? Bird Study 1984, 31, 195-202. [CrossRef]

49. Laiolo, P.; Dondero, F.; Ciliento, E.; Rolando, A. Consequences of pastoral abandonment for the structure and diversity of the alpine avifauna. J. Appl. Ecol. 2004, 41, 294-304. [CrossRef]

50. Krebs, C.J. Ecological Methodology; Addison Wesley Longman: Boston, MA, USA, 1998; p. 624.

51. Kontsiotis, V.; Zaimes, G.N.; Tsiftsis, S.; Kiourtziadis, P.; Bakaloudis, D. Assessing the influence of riparian vegetation structure on bird communities in agricultural Mediterranean landscapes. Agrofor. Syst. 2019, 93, 675-687. [CrossRef]

52. BirdLife International. European Birds of Conservation Concern: Populations, Trends and National Responsibilities; BirdLife International: Cambridge, UK, 2017; ISBN 978-1-912086-00-9.

53. Rice, W.R. Analyzing tables of statistical tests. Evolution 1989, 43, 223-225. [CrossRef] [PubMed]

54. Murtaugh, P.A. Performance of several variable-selection methods applied to real ecological data. Ecol. Lett. 2009, 12, 1061-1068. [CrossRef] [PubMed]

55. Burnham, K.P.; Anderson, D.R. Model Selection and Multimodel Inference; Springer: New York, NY, USA, $2002 ;$ p. 488.

56. McCune, B.; Mefford, M.J. PC-ORD. Multivariate Analysis of Ecological Data 1999; Version 4; MjM Software Design: Gleneden Beach, OR, USA, 1999.

57. Dufrêne, M.; Legendre, P. Species assemblages and indicator species: The need for a flexible asymmetrical approach. Ecol. Monogr. 1997, 67, 345-366. [CrossRef]

58. McCune, B.; Grace, J.B. Analysis of Ecological Communities; MjM Software: Gleneden Beach, OR, USA, 2002 ; p. 300.

59. Sutherland, W.J. Ecological Census Techniques: A Handbook, 2nd ed.; Cambridge University Press: New York, NY, USA, 2006; p. 446.

60. Bilotta, G.S.; Brazier, R.E.; Haygarth, P.M. The impacts of grazing animals on the quality of soils, vegetation, and surface waters in intensively managed grasslands. Adv. Agron. 2007, 94, 237-280. [CrossRef]

61. Fisher, R.J.; Davis, S.K. From wiens to robel: A review of grassland-bird habitat selection. J. Wildl. Manag. 2010, 74, $265-273$. [CrossRef] 
62. Dias, R.A.; Bastazini, V.A.G.; Gianuca, A.T. Bird-habitat associations in coastal rangelands of southern Brazil. Iheringia Ser. Zool. 2014, 104, 200-208. [CrossRef]

63. Fuller, R.J.; Gough, S.J. Changes in sheep numbers in Britain: Implications for bird populations. Biol. Conserv. 1999, 91, 73-89. [CrossRef]

64. Butler, S.J.; Gillings, S. Quantifying the effects of habitat structure on prey detectability and accessibility to farmland birds. Ibis (Lond. 1859) 2004, 146, 123-130. [CrossRef]

65. Leal, A.I.; Acácio, M.; Meyer, C.F.J.; Rainho, A.; Palmeirim, J.M. Grazing improves habitat suitability for many ground foraging birds in Mediterranean wooded grasslands. Agric. Ecosyst. Environ. 2019, 270-271, 1-8. [CrossRef]

66. Whittingham, M.J.; Evans, K.L. The effects of habitat structure on predation risk of birds in agricultural landscapes. Ibis (Lond. 1859) 2004, 146, 210-220. [CrossRef]

67. Vickery, J.A.; Tallowin, J.R.; Feber, R.E.; Asteraki, E.J.; Atkinson, P.W.; Fuller, R.J.; Brown, V.K. The management of lowland neutral grasslands in Britain: Effects of agricultural practices on birds and their food resources. J. Appl. Ecol. 2001, 38, 647-664. [CrossRef]

68. Kotsonas, E.; Bakaloudis, D.; Papakosta, M.; Goutner, V.; Chatzinikos, E.; Vlachos, C. Assessment of nestling diet and provisioning rate by two methods in the lesser kestrel falco naumanni. Acta Ornithol. 2017, 52, 149-156. [CrossRef]

69. Toepfer, S.; Stubbe, M. Territory density of the Skylark (Alauda arvensis) in relation to field vegetation in central Germany. J. Ornithol. 2001, 142, 184-194. [CrossRef]

70. Handrinos, G.; Akriotis, T. The Birds of Greece; Christopher Helm Ltd.: London, UK, 1997; p. 336.

71. Herman van Oostern, H.; van den Burg, A.B.; Versluijs, R.; Siepel, H. Habitat selection of broodrearing Northern Wheatear Oenanthe oenanthe and their invertebrate prey. Ardea 2014, 102, 61-69.

72. BirdLife International. Oenanthe Oenanthe. The IUCN Red List of Threatened Species 2018: e.T103773898A132192232. Available online: http:/ / dx.doi.org/10.2305/IUCN.UK.2018-2.RLTS.T103773898A132192232.en (accessed on 30 November 2018).

73. Grzybek, J.; Michalak, I.; Osiejuk, T.S.; Tryjanowski, P. Densities and habitats of the tawny pipit anthus campestris in the Wielkopolska region (W Poland). Acta Ornithol. 2008, 43, 221-225. [CrossRef]

74. Sánchez, S.; Václav, R.; Prokop, P. An inter-regional approach to intraspecific variation in habitat association: Rock buntings emberiza cia as a case study. Ibis (Lond. 1859) 2009, 151, 88-98. [CrossRef]

75. Verhulst, J.; Báldi, A.; Kleijn, D. The relation between land-use intensity and species-richness and abundance of birds in Hungary. Agric. Ecosyst. Environ. 2004, 104, 465-473. [CrossRef]

76. Báldi, A.; Batáry, P.; Erdős, S. Effects of grazing intensity on bird assemblages and populations of Hungarian grasslands. Agric. Ecosyst. Environ. 2005, 108, 251-263. [CrossRef]

77. Azpiroz, A.B.; Isacch, J.P.; Dias, R.A.; Di Giacomo, A.S.; Fontana, C.S.; Palarea, C.M. Ecology and conservation of grassland birds in southeastern South America: A review. J. F. Ornithol. 2012, 83, 217-246. [CrossRef]

78. Vickery, P.D.; Tubaro, P.L.; Da Silva, J.M.C.; Peterjohn, B.G.; Herkert, J.R.; Cavalcanti, R.B. Conservation of grassland birds in the western hemisphere. In Studies in Avian Biology; Cooper Ornithological Society: Camarillo, CA, USA, 1999; Volume 19, pp. 2-26.

79. Isacch, J.P.; Cardoni, D.A. Different grazing strategies are necessary to conserve endangered grassland birds in short and tall salty grasslands of the flooding pampas. Condor 2011, 113, 724-734. [CrossRef]

80. Codesido, M.; González-Fischer, C.M.; Bilenca, D.N. Land bird assemblages in different agricultural landscapes: A case study in the pampas of Central Argentina. BioOne 2013, 115, 8-16.

81. Hovick, T.J.; Elmore, R.D.; Fuhlendorf, S.D.; Engle, D.M.; Hamilton, R.G. Spatial heterogeneity increases diversity and stability in grassland bird communities. Ecol. Appl. 2015, 25, 662-672. [CrossRef]

82. Cramp, S.; Perrins, C.M. Handbook of the Birds of Europe, the Middle East and North Africa; the Birds of the Western Palearctic, Vol. V: Tyrant Flycatchers to Thrushes; Oxford University Press: Oxford, UK, 1988; p. 1084.

83. Cramp, S.; Simmons, K.E.L. Handbook of the Birds of Europe, the Middle East and North Africa: Birds of the Western Palearctic. Vol. II: Hawks to Bustards; Oxford University Press: Oxford, UK, 1980; p. 695.

84. Cramp, S.; Perrins, C.M. Handbook of the Birds of Europe, the Middle East and North Africa: Birds of the Western Palearctic. Vol. IX: Buntings and New World Warblers; Oxford University Press: Oxford, UK, 1994; p. 496.

85. Cramp, S.; Perrins, C.M. Handbook of the Birds of Europe, the Middle East and North Africa: Birds of the Western Palearctic. Vol. VII: Flycatchers to Shrikes; Oxford University Press: Oxford, UK, 1993; p. 586.

86. Cramp, S.; Perrins, C.M. Handbook of the Birds of Europe, the Middle East and North Africa: Birds of the Western Palearctic. Vol. VIII: Crows to Finches; Oxford University Press: Oxford, UK, 1994; p. 906.

87. Cramp, S. Handbook of the Birds of Europe, the Middle East and North Africa: Birds of the Western Palearctic. Vol. VI: Warblers; Oxford University Press: Oxford, UK, 1992; p. 735. 